\title{
Mercury Sources to Lake Ozette and Lake Dickey: Highly Contaminated Remote Coastal Lakes, Washington State USA
}

\author{
Chad V. Furl \\ Washington State Department of Ecology. \\ 300 Desmond Dr. \\ Olympia, WA 98504, USA \\ email: cfur461@ecy.wa.gov \\ phone: 360-407-6060 \\ fax: 360-407-6884 \\ John A. Colman \\ U. S. Geological Survey \\ 10 Bearfoot Road \\ Northborough, MA, USA \\ Michael H. Bothner \\ U.S. Geological Survey \\ 384 Woods Hole Road \\ Woods Hole, MA, USA
}

\begin{abstract}
Mercury concentrations in largemouth bass and mercury accumulation rates in age-dated sediment cores were examined at Lake Ozette and Lake Dickey in Washington State. Goals of the study were to compare concentrations in fish tissues at the two lakes with lakes in a larger statewide dataset and evaluate factors influencing lake loading at Ozette and Dickey, which may include: catchment disturbances, coastal mercury cycling, and the role of trans-Pacific Asian mercury. Mercury fish tissue concentrations at the lakes were among the highest recorded in Washington State. Wet deposition and historical atmospheric monitoring from the area show no indication of enhanced deposition from Asian sources or coastal atmospheric processes. Sediment core records from the lakes displayed rapidly increasing sedimentation rates coinciding with commercial logging. The unusually high mercury flux rates and mercury tissue concentrations recorded at Lake Ozette and Lake Dickey appear to be associated with logging within the catchments.
\end{abstract}

Keywords Mercury $\cdot$ Lake Ozette $\cdot$ Logging $\cdot$ Sediment cores $\cdot$ Atmospheric deposition $\cdot$ Lake Dickey 


\section{Introduction}

Mercury contamination of aquatic food webs is a widespread global phenomenon with mercury levels found in remote aquatic ecosystems rendering fish unsuitable for consumption (Fitzgerald et al. 1998). Anthropogenic mercury releases from coal combustion and waste incineration, for example, have severely altered the natural mercury cycle. Once mercury is emitted to the atmosphere it can be transported globally depending on its chemical speciation (Schroeder and Munthe 1998).

The complex biogeochemical cycling characteristics of mercury make it difficult to identify the important factors influencing loading and subsequent biological uptake at any single lake location. Land use activity leading to increased soil erosion can result in increased mercury export from watersheds, enhancing fluxes to waterbodies (Engstrom et al. 2007; Grigal 2002). Additionally, marine atmospheric boundary layer processes influencing mercury speciation may have implications for enhanced loading in coastal settings (Malcolm and Keeler 2003).

Recent mercury monitoring of largemouth bass (Micropterus salmoides) in Washington State has resulted in a large database to evaluate differences in tissue concentrations among lakes (Fischnaller et al. 2003; Furl et al. 2007; Furl 2007; Furl and Meredith 2008). Unexpectedly, the highest mercury concentrations were found at Lake Ozette and Lake Dickey located in the remote coastal region of the Olympic Peninsula. We examined available mercury concentrations among largemouth bass from 24 lakes in Washington State, mercury accumulation in age-dated sediment cores from Lake Ozette and Lake Dickey, and wet deposition data from a national Mercury Deposition Network (MDN) station near Lake Ozette and Lake Dickey. Specific goals of the study are to compare levels of mercury contamination in largemouth bass at the remote lakes with lakes in the larger statewide dataset and evaluate factors influencing lake loading at Lake Ozette and Lake Dickey which may include: catchment disturbances, coastal mercury cycling, and the role of trans-Pacific Asian mercury.

\section{Methods}

\subsection{Setting}

Located within the coastal strip of the Olympic National Park $5 \mathrm{~km}$ from the Pacific Ocean, Lake Ozette is the third largest natural lake in Washington State with a surface area of $29.5 \mathrm{~km}^{2}$ and an average depth of $40 \mathrm{~m}$ (Bortleson et al. 1976) (Figure 1). The National Park Service owns $15 \%$ of the $118 \mathrm{~km}^{2}$ drainage basin while over $80 \%$ of the lake catchment is zoned as commercial forest land. Approximately $60 \%$ of the Ozette drainage basin flows to the lake by three large creeks. In addition to three main inflows, numerous unnamed perennial streams contribute surface water to Lake Ozette. The lake is drained by the Ozette River at its north end into the Pacific Ocean. The average lake level is $10 \mathrm{~m}$ above sea level; drainage basin elevations range up to $580 \mathrm{~m}$. Watershed geology consists of glacio-fluvial deposits situated between resistant marine deposited sedimentary rocks. Human population of the Lake Ozette watershed is estimated to be less than 100 (Haggerty et al. 2007).

Lake Dickey is located approximately $10 \mathrm{~km}$ directly east of Lake Ozette outside of the Olympic National Park at $59 \mathrm{~m}$ above sea level (Figure 1). The lake is considerably smaller than Ozette with an area of $2 \mathrm{~km}^{2}$ and an average depth of $7.6 \mathrm{~m}$. The lake receives perennial inputs from the $38.1 \mathrm{~km}^{2}$ drainage basin and is drained by a small outflow at its south end flowing to the Quillayute River (Bortleson et al. 1976).

Forests within the catchments can be classified as a coastal temperate rainforest. Both catchments are dominated by coniferous species, and commercial logging is the largest land-use activity with private timber companies owning the majority of the land. The nearest urban population centers are Seattle and Vancouver, BC located approximately $180 \mathrm{~km}$ to the east. Climate in the area can be characterized as temperate coastal-marine, resulting in mild winters and cool summers. Average annual precipitation in the area is in excess of $250 \mathrm{~cm}$ per year with greater than $80 \%$ occurring between October and April. Fog drip is also believed to be a large contributor to ground surface precipitation. Air flows from the west occur greater than $50 \%$ of the time at the nearest weather station $20 \mathrm{~km}$ to the south of Lake Ozette (Haggerty et al. 2007). 
In addition to Lake Ozette and Lake Dickey, mercury tissue concentrations were examined among 22 additional Washington State lakes (referred to as statewide lakes) to determine if tissue concentrations at Lake Ozette and Lake Dickey were significantly different from the statewide lakes. Diverse morphology, hydrology, and land uses are found amongst the statewide group (Fischnaller et al. 2003; Furl et al. 2007; Furl 2007; Furl and Meredith 2008) (Figure 1 and Table 1).

Table 1 Lake information

\begin{tabular}{|c|c|c|c|c|c|c|c|}
\hline Lake & $\begin{array}{c}\text { Surface } \\
\text { Area } \\
\left(\mathrm{km}^{2}\right) \\
\end{array}$ & $\begin{array}{c}\text { Drainage } \\
\text { Area } \\
\left(\mathrm{km}^{2}\right) \\
\end{array}$ & $\begin{array}{c}\text { Max } \\
\text { Depth } \\
(\mathrm{m}) \\
\end{array}$ & $\begin{array}{l}\text { Avg. } \\
\text { Depth } \\
(\mathrm{m})\end{array}$ & $\begin{array}{c}\text { Collection } \\
\text { Date }\end{array}$ & $\begin{array}{c}\text { Avg. } \\
\text { Rainfall } \\
1982- \\
2007 \\
(\mathrm{~cm})\end{array}$ & Study \\
\hline Dickey & 2.0 & 38.1 & 13.7 & 7.6 & $8 / 15 / 2007$ & 276.7 & $\begin{array}{l}\text { Colman et al. } 2009 \\
\text { manuscript in prep. }\end{array}$ \\
\hline Ozette & 29.5 & 118.0 & 97.5 & 40.0 & $9 / 12 / 2007$ & 250.0 & Furl and Meredith $2008^{b}$ \\
\hline Deer & 4.5 & 47.1 & 22.9 & 15.8 & 9/18/2007 & 53.6 & $"$ \\
\hline Fazon & 0.1 & 2.4 & 5.2 & 3.0 & $9 / 5 / 2007$ & 113.1 & $"$ \\
\hline Lower Goose & 0.2 & - & 22.9 & 7.6 & 9/19/2007 & 21.1 & $"$ \\
\hline St. Clair & 0.4 & 37.6 & 33.5 & 12.2 & $8 / 23 / 2007$ & 141.3 & $"$ \\
\hline Samish & 2.8 & 23.8 & 22.9 & 9.4 & 9/4/2007 & 105.7 & " \\
\hline Moses & 27.5 & $7,976.9$ & 11.6 & 5.8 & $10 / 9 / 2006$ & 24.6 & Furl $2007^{b}$ \\
\hline Newman & 4.9 & 74.1 & 9.1 & 5.8 & $9 / 27 / 2006$ & 47.2 & $"$ \\
\hline Offut & 0.8 & 7.0 & 7.6 & 4.6 & $10 / 30 / 2006$ & 138.5 & $"$ \\
\hline Sammamish & 19.8 & 253.8 & 32.0 & 17.7 & $10 / 4 / 2006$ & 110.0 & $"$ \\
\hline Meridian & 0.6 & 3.0 & 27.4 & 12.5 & $10 / 5 / 2006$ & 136.9 & " \\
\hline Loon & 4.6 & 36.5 & 30.5 & 14.0 & $10 / 26 / 2005$ & 60.7 & Furl et al. $2007^{b}$ \\
\hline Silver & 9.3 & 101.8 & 3.0 & 1.8 & 9/22/2005 & 308.0 & " \\
\hline Banks & 1.1 & - & 25.9 & 14.3 & $11 / 7 / 2001$ & 21.8 & Fischnaller et al. $2003^{c}$ \\
\hline Terrell & 1.8 & 7.4 & 3.0 & 2.1 & $9 / 26 / 2001$ & 86.2 & $"$ \\
\hline Long & - & - & 54.9 & 14.6 & $6 / 18 / 2001$ & 47.4 & $"$ \\
\hline Vancouver & 9.3 & - & 4.6 & 1.0 & $10 / 3 / 2002$ & 105.6 & $"$ \\
\hline Black & 2.3 & 26.2 & 8.8 & 5.8 & 10/7/2002 & 116.0 & $"$ \\
\hline Duck & 1.1 & 3.7 & 9.1 & 3.4 & $10 / 10 / 2002$ & 193.2 & $"$ \\
\hline Loomis & 0.7 & 3.7 & 2.7 & 1.5 & 10/11/2002 & 204.2 & $"$ \\
\hline Palmer & 8.5 & 766.6 & 24.1 & 15.5 & $10 / 15 / 2002$ & 36.7 & $"$ \\
\hline Kitsap & 1.0 & 7.1 & 8.8 & 5.5 & $10 / 31 / 2002$ & 99.2 & " \\
\hline Padden & 0.6 & 6.8 & 18.0 & 8.2 & 9/27/2001 & 100.1 & Seiders $2003^{c}$ \\
\hline
\end{tabular}

${ }^{\text {a }}$ Analytical method EPA 7473

${ }^{b}$ Analytical method EPA 245.6

${ }^{\mathrm{c}}$ Analytical method EPA 245.5

2.2 Fish Tissue Collection, Processing, and Analysis

Largemouth bass were collected by electroshocking and gillnetting from $2001-2007$. Fish were measured, double wrapped in aluminum foil, placed on ice in the field, and frozen $\left(-20^{\circ} \mathrm{C}\right)$ within 72 hours of collection until further processing. Fish from Lake Dickey were filleted skin-off in the field and shipped on ice overnight to the laboratory of William X. Wall Experiment Station, Massachusetts Department of Environmental Protection, in Lawrence, Massachusetts for analysis. 
Fish were prepared for analysis by filleting with skin left on, passed three times through a Kitchen-Aid food grinder, and homogenized to a uniform color and texture. Utensils contacting the samples were cleaned using sequential rinses with tap water, Liquinox detergent and hot tap water, $10 \%$ nitric acid, and deionized water. Tissues were analyzed using EPA Method 245.5, 245.6, or 7473 (Table 1).

Quality control for tissue analysis included analysis of laboratory control samples (80 - 120\%), standard reference material $( \pm 15 \%)$, method blanks, matrix spike recoveries $(75-125 \%)$, and matrix spike duplicates $(<25 \%$ RPD) . Data were generally good across all lakes with the exception of inadequate matrix spike duplicates ( $>25 \%$ RPD) at Duck Lake. Detailed methodology descriptions and results for tissue monitoring is included in Fischnaller et al. (2003), Furl et al. (2007), Furl (2007), Furl and Meredith (2008), and Colman et al. manuscript in prep. (2009).

\subsection{Sediment Core Collection, Processing, and Analysis}

Sediment cores were collected using a 13x13x50 cm Wildco box corer containing an acrylic liner. Cores were collected from deep areas of the lake with uniform bathymetry removed from significant surface water inputs. Cores reflecting the least disturbed sediments and a distinct sediment-water interface were immediately sectioned in the field. Subsamples were extruded in 1-cm intervals for the entire length of the core, stored in pre-cleaned 8oz Nalgene bottles, and placed on ice in the field. One sediment core was collected at Lake Ozette while two cores from approximately the same location were collected at Lake Dickey.

Sediment cores were analyzed for ${ }^{210} \mathrm{~Pb}$ activity in order to assign dates and sedimentation rates over the past $100-150$ years. For Lake Ozette, ${ }^{210} \mathrm{~Pb}$ activity was determined in selected composites comprised of two to three 1-cm intervals using gamma spectroscopy for 1000 minutes per sample. Samples were measured to a method detection limit of at least $0.45 \mathrm{pCi} / \mathrm{g}$. Sample counts were done in one batch, and quality control measures consisted of one control sample, one method blank, and one duplicate. The control samples were recovered at an average of $104 \%$, the method blanks were not detected above 0.300 $\mathrm{pCi} / \mathrm{g}$, and duplicates had a relative percent difference of $1.8 \%$. For Lake Dickey, ${ }^{210} \mathrm{~Pb}$ activity was determined for each 1-cm horizon at Lake Dickey using planar germanium detectors counting gamma ray emissions for $48-96$ hours, which provided an average ${ }^{210} \mathrm{~Pb}$ counting error of less than $2.6 \%$. A correction for self-absorption was made based on the geometry of the gamma-counted sample (Cutshall et al. 1983). Accuracy was confirmed by analyses of standard reference materials, which yielded agreement within 5\% of certified values.

Mercury analyses for selected 1-cm intervals from the Lake Ozette core were conducted by the Washington State Department of Ecology's Manchester Environmental Laboratory using EPA method 245.5. Matrix spikes, blanks, and control samples were included for quality assurance. Two matrix spikes were recovered at $82 \%$ and $84 \%$ respectively. A single blank was undetected at $0.0050 \mathrm{ppb}$ and two control samples were recovered at $104 \%$ and $111 \%$. The data were not adjusted for matrix spike recoveries. Sediment mercury analyses for Lake Dickey were conducted by the Wall Experiment Station where tissue analyses were performed. EPA Method 7473 was used for the determination of mercury concentrations on freeze dried sediments. Average of 26 measurements of standard reference material was 101 percent of standard, range of 85 to 115 percent; spike recoveries ranged from 99 to 102 percent. Detailed methodology descriptions and results for the sediment cores are included in Furl (2007a), Furl (2008), and Colman et al. manuscript in prep. (2009a).

\subsection{Age and Sedimentation Rate Calculations}

The constant rate of supply (CRS) model was used to estimate dates and varying sedimentation rates throughout the cores (Appleby and Oldfield 1978). For Lake Ozette, supported ${ }^{210} \mathrm{~Pb}$ was estimated as the amount of ${ }^{210} \mathrm{~Pb}$ present at deep intervals where it appeared to no longer decline. Lake Dickey supported

${ }^{210} \mathrm{~Pb}$ levels were determined from ${ }^{222} \mathrm{Rn}$ assays in each $1-\mathrm{cm}$ horizon. An assumed sediment density of 2.5 $\mathrm{g} / \mathrm{cm}^{3}$ was used to compute dry mass for core dating. 
Several horizons were analyzed for mercury without an accompanying ${ }^{210} \mathrm{~Pb}$ measurement in the Lake Ozette core. Dates were assigned to these measurements by working back in time from the most recent

${ }^{210} \mathrm{~Pb}$ derived date using an estimated interval mass accumulation rate (MAR) modeled from the ${ }^{210} \mathrm{~Pb}$ sedimentation curve along with the mass of the interval:

$$
\text { Date } \left._{i}=\right)_{\text {ate }}{ }_{P b}-\mathrm{Cum}_{i} / \mathrm{MAR}_{i}^{-}
$$

Where

Date $_{\mathrm{i}}=$ deposition date of sample without ${ }^{210} \mathrm{~Pb}$ measurements,

Date $_{\mathrm{Pb}}=$ date assigned to the bottom of the interval last measured for ${ }^{210} \mathrm{~Pb}$,

$\mathrm{Cum}_{\mathrm{i}}=$ cumulative mass from Date $_{\mathrm{i}}$ to midpoint of sample $\mathrm{i}$,

$\mathrm{MAR}_{\mathrm{i}}=$ interval MAR for sample $\mathrm{i}$ estimated from the ${ }^{210} \mathrm{~Pb}$ derived MAR curve.

Mercury flux rates $\left(\mu \mathrm{g} / \mathrm{m}^{2} / \mathrm{yr}\right)$ were calculated as the product of the sedimentation rate and dry weight mercury concentration. The results estimate net deposition to the lake.

\subsection{Statistical Calculations}

Differences among Lake Ozette and Lake Dickey tissue concentrations were examined by regressing mercury concentration against fish length and examining differences in the slope of the best fit line using a t-test. Tissue concentrations from each of the 22 statewide lakes were then compared to the combined Ozette and Dickey data using an analysis of covariance with a post hoc Dunnett's test. Length was selected as the covariate to isolate the effect of fish size on mercury concentrations. After the model accounted for variability associated with regression of mercury concentration on fish length, mean mercury concentrations for each lake were compared to Lake Ozette and Lake Dickey. Data for the statewide comparison were $\log _{10}$ transformed to improve the normality of the data. The analysis is designed to show which lakes accumulate mercury at higher rates based on fish length. Statistical calculations were performed with Minitab.

\section{Results}

\subsection{Fish Tissue}

Mercury concentrations in fillets from Lake Ozette and Lake Dickey largemouth bass ranged from 190 $2,500 \mathrm{ng} / \mathrm{g}$ ww $(\mathrm{n}=17)$. Mean tissue concentrations were 715 and $889 \mathrm{ng} / \mathrm{g}$ for Lake Ozette and Lake Dickey, respectively. Average fish length was slightly greater at Lake Dickey $(358 \mathrm{~mm})$ than Lake Ozette (342 mm). Length explained $49 \%$ and $83 \%$ of the variability in mercury concentrations for Ozette and Dickey, respectively (Figure 2). The slopes of the regression lines did not significantly differ $(\mathrm{p}>0.05, \mathrm{~F}=$ 2.14), suggesting fish at both lakes accumulate mercury at similar rates based on fish length.

Comparisons made between each of the 22 statewide lakes and the combined data of Lake Ozette and Lake Dickey found mean mercury concentrations at each lake to be significantly lower in all cases than the combined data from Lake Ozette and Lake Dickey $(\mathrm{p}<0.001, \mathrm{~F}=52.01, \mathrm{DF}=22)$. The analysis shows largemouth bass at Lake Ozette and Lake Dickey accumulate mercury at higher rates based on length compared to the other 22 statewide lakes. Figure 3 displays regression of mercury concentrations against fish length for the combined Lake Ozette and Lake Dickey data along with other statewide lakes.

\subsection{Sediment Cores}

Sedimentation rates at the three coring locations ranged from $0.02-0.12 \mathrm{~g} / \mathrm{cm}^{2} / \mathrm{yr}$ with the highest sedimentation rates occurring at or near the top or the core. Unsupported atmospheric ${ }^{210} \mathrm{~Pb}$ fluxes estimated from core inventories were $0.72,0.77$, and $0.93 \mathrm{pCi} / \mathrm{cm}^{2} / \mathrm{yr}$ at Dickey 1, Dickey 2, and Ozette, respectively. Typically, unsupported ${ }^{210} \mathrm{~Pb}$ fluxes calculated from measured data fall within $0.2-1.0$ 
$\mathrm{pCi} / \mathrm{cm}^{2} / \mathrm{yr}$ (Appleby and Oldfield 1984). The greatest incremental increases in sedimentation rates occur during the last half of the $20^{\text {th }}$ century. Recent mercury flux rates estimated from the uppermost core horizon ranged from $196 \mu \mathrm{g} / \mathrm{m}^{2} / \mathrm{yr}$ at Ozette to $249 \mu \mathrm{g} / \mathrm{m}^{2} / \mathrm{yr}$ at Dickey 2. Post-1950 dry weight concentrations varied little at the Dickey cores $200-230 \mathrm{ng} / \mathrm{g}(\mathrm{n}=39)$ with the exception of a single anomalous value in the $2-3 \mathrm{~cm}$ horizon of Dickey $2(140 \mathrm{ng} / \mathrm{g})$. Dry weight concentrations in the Ozette core experienced a slightly more erratic pattern with a narrow range of concentrations during the same post-1950 time period $(170-271 \mathrm{ng} / \mathrm{g}, \mathrm{n}=9)$. Sediment core profiles displaying sedimentation, mercury concentration, and mercury flux for all three cores are displayed in Figure 4.

\subsection{Regional Atmospheric Deposition}

Preliminary wet deposition data measured by an MDN station $15 \mathrm{~km}$ from the north end of Lake Ozette recorded deposition of $7.77 \mu \mathrm{g} / \mathrm{m}^{2}$ from March 2007- February 2008. Average monthly volume weighted mercury concentration in precipitation was $4.51 \mathrm{ng} / \mathrm{L}$. Concentrations in precipitation were low and experienced little variability with the exception of August when they were nearly 4 times the average $(16.98 \mathrm{ng} / \mathrm{L})$. Higher concentrations in summer precipitation are typical among MDN sites (Mercury Deposition Network 2008). Deposition rates were strongly influenced by rainfall which was approximately $200 \mathrm{~cm}$ during the sampling period. Annual deposition measured concurrently at a Seattle MDN site was $6.99 \mu \mathrm{g} / \mathrm{m}^{2}$ with a monthly average volume weighted concentration of $12.11 \mathrm{ng} / \mathrm{L}$ in precipitation. The Seattle site received approximately $40 \%$ of the rainfall $(75 \mathrm{~cm})$ collected at the Ozette station with similar deposition values. Higher mercury concentrations in precipitation recorded at the Seattle station are presumably the result of local point sources. The low variance recorded in monthly precipitation concentrations at the Ozette site compared to the Seattle station ( $\mathrm{SD}=4.1$ and 7.0 respectively) suggest that the Ozette station is not affected by the same point sources. Additionally, atmospheric measurements of mercury recorded over a 13 month period (2002-2003) $15 \mathrm{~km}$ north of Ozette at Cheeka Peak Observatory (CPO) were $1.5 \mathrm{ng} / \mathrm{m}^{3}$ (Weiss-Penzias et al. 2003), consistent with the northern hemisphere background (Temme et al. 2003). Atmospheric concentrations in the Seattle metro area averaged $2.5 \mathrm{ng} / \mathrm{m}^{3}$ over a two year period from 1994-1995 (Bloom et al. 1995).

\section{Discussion}

Considering the remote location of Lake Ozette and Lake Dickey it was unexpected to find significantly higher mercury concentrations in fish tissues when compared to lakes statewide. Many factors have been correlated with elevated tissue concentrations in past investigations including $\mathrm{pH}$, sulfate, chloride, and DOC (Grieb et al. 1990; Hanten et al. 1998; Hrabik and Watras 2002). These constituents were measured in the water column from Lake Ozette along with 29 other randomly selected statewide lakes as part of the U.S. Environmental Protection Agency's 2007 National Lake Assessment. Lake Ozette concentrations for all 4 parameters were within 1 standard deviation of the dataset mean (Maggie Bell-Mckinnon, personal communication). No data were obtained for Lake Dickey. Mercury mining, which has contaminated many drainages in the west, also is not spatially correlated with the tissue concentrations observed in this investigation. Mercury mining has been prevalent in the cental part of the state but is absent on the Olympic Peninsula (USGS 2007). Point sources within the immediate vicinity of Lake Ozette and Lake Dickey are lacking; however, using available wet deposition/atmospheric mercury data and the sediment core records from the lakes, three possible sources of mercury to the lakes are evaluated.

\subsection{Effects of Watershed Disturbance on Mercury Loading}

Mercury flux rates measured in the uppermost intervals of sediment cores of Lake Ozette and Dickey Lake $\left(\approx 200 \mu \mathrm{g} / \mathrm{m}^{2} / \mathrm{yr}\right)$ were greater than fluxes measured in other coring studies in regional remote locations. Landers et al. (2008) found recent mercury fluxes were generally less than $50 \mu \mathrm{g} / \mathrm{m}^{2} / \mathrm{yr}$ at two lakes located within the interior of the Olympic National Park and two lakes within Mount Rainier National Park, WA. Furl (2008) estimated mercury fluxes were less than $50 \mathrm{ug} / \mathrm{m}^{2} / \mathrm{yr}$ in two eastern Washington lakes removed from point sources.

Examination of dry weight mercury concentrations and sedimentation rates reveal sedimentation at Lake Ozette and Lake Dickey is the dominant factor responsible for the increase in modern flux rates (Figure 5). 
Post-1950 mercury flux rates correlated strongly with sedimentation rates at lake Ozette $(\mathrm{r}=0.925)$ and sedimentation rates explained $86 \%$ of the variance in flux rates $(\mathrm{F}=23.8, \mathrm{p}<0.05)$. Conversely, mercury concentrations at Lake Ozette had no correlation with flux rates $(\mathrm{r}=0.032)$ and explained $0 \%$ of the variance in mercury flux $(\mathrm{F}=0.004, \mathrm{p}>0.05)$. A similar relationship was found between the variables in the Lake Dickey cores. Correlations between flux and sedimentation were strong for Lake Dickey core 1 and core $2(r=0.995$ and $r=0.947$, respectively), and sedimentation explained $99 \%$ and $90 \%$ of the variance in flux ( $\mathrm{F}=1774, \mathrm{p}<0.05 ; \mathrm{F}=157, \mathrm{p}<0.05$, respectively). Concentration had a weak correlation with flux rate at Dickey $1(\mathrm{r}=0.412)$ and no correlation at Dickey $2(\mathrm{r}=0.040)$. Concentration explained $17 \%$ and $0 \%$ of the variance in flux rates at Dickey 1 and Dickey 2 , respectively $(\mathrm{F}=3.485, \mathrm{p}>0.05 ; \mathrm{F}=$ $0.029, \mathrm{p}>0.05)$ These findings are contrary to those of Engstrom et al. (2007) who found a negative correlation between sediment accumulation and dry weight concentrations over a large dataset of 55 Minnesota cores. The authors explained this relationship as increased sedimentation having a diluting effect on atmospheric inputs.

Logging in the catchment has been determined to be the source of increased sedimentation within the Lake Ozette catchment (Haggerty et al. 2007; Ritchie 2009; Herrera 2006). Currently, only 20\% of the Lake Ozette catchment remains as primary forest (Ritchie 2009). Herrera (2006) estimated current sedimentation rates to be at least 3 times greater than pre-logging levels. Haggerty et al. (2007) attributed elevated sedimentation rates at Ozette to high road density and a large percentage of hydrologically immature forest due to logging. The sediment cores from Ozette and Dickey indicate current sedimentation rates are 4 times higher than average baseline values. Figure 6 displays sedimentation rates estimated from the cores plotted with remaining primary forest as a percent of watershed in the Lake Ozette catchment reconstructed from aerial photography (Ritchie 2009).

Increased terrestrial output of mercury to lake ecosystems resulting from clear-cut logging practices have been recorded elsewhere. In a 7 year study, Porvari et al. (2003) found significant increases in the total mercury and methylmercury load in runoff water after clear-cutting in a small forested catchment in Norway. Additionally, similar to the present study, the authors found no increase in mercury concentrations, but rather an increase in total flux due to elevated water runoff. The effects of logging practices on lake biota have also been studied in Quebec. Significantly higher concentrations of mercury in zooplankton were observed in lakes with recently logged watersheds compared to lakes with undisturbed or recently burned watersheds (Garcia and Carignan 1999). The same authors found mercury concentrations to be significantly higher in northern pike in logged watersheds compared with undisturbed catchments (Garcia and Carignan 2000). No other lake catchments included in the statewide tissue statistical analysis have been as extensively logged in recent times as Lake Ozette and Lake Dickey.

\subsection{Coastal Effects on Mercury Deposition}

The role of coastal mercury cycling was also considered in examining mercury deposition to the lakes. Studies investigating mercury cycling and deposition at coastal environments have focused on in situ production of reactive gaseous mercury (RGM) and the role of sea salt aerosols on particulate deposition (Laurier and Mason 2007; Engle et al. 2008; Malcolm and Keeler 2003). RGM is an important factor in evaluating atmospheric deposition as it is easily scavenged from the atmosphere via wet or dry deposition.

Rapid production of atmospheric RGM has been recorded in arctic environments and termed mercury depletion events (eg. Lindberg et al. 2002). Similar diurnal patterns in RGM have been documented at coastal and open ocean areas, correlating temporally with UV radiation, resulting in mid-day maximums and night time minimums. Accumulating evidence suggests the cycle is mediated by reactive halogen particles liberated from sea salt aerosols resulting in $\mathrm{O}_{3}$ destruction and RGM production (Laurier and Mason 2007; Hedgecock and Pironne 2001). During atmospheric mercury monitoring conducted at CPO, Weiss-Penzias et al. (2003) measured RGM in 4 hour intervals from September 2001 - May 2002. RGM concentrations from marine segregated air masses were nearly always less than the detection limit (1.6 $\mathrm{pg} / \mathrm{m}^{3}$ ) suggesting the marine boundary layer is not a significant source of readily deposited mercury in the area. Continental flows brought occasionally enhanced RGM air masses $\left(10-20 \mathrm{pg} / \mathrm{m}^{3}\right)$, but were generally very low $\left(<2.0 \mathrm{pg} / \mathrm{m}^{3}\right)$. The low RGM concentrations are in contrast to similar studies at other coastal locations (Laurier and Mason 2007; Engle et al. 2008; Malcolm and Keeler 2003). RGM 
measurements at CPO were not recorded during the summer months (June, July, August) when UV radiation and RGM would be expected to be at their highest. The low RGM concentrations measured at the site may result from the cloudy conditions found on the Olympic Peninsula. Near continuous cloud cover during the winter months could limit the UV radiation required for photochemically produced RGM.

Particulate deposition of mercury has also been suggested as an important pathway for mercury deposition in coastal areas. In a study along the coast of Rhode Island, Malcolm et al. (2003) hypothesized a mass transfer of atmospheric mercury to coarse sea salt particles to account for concentrations in particulates that could not be explained by mercury concentrations in seawater alone. Additionally, Engle et al. (2008) found mercury concentrations in particulates to increase with proximity to the ocean. Particulates were monitored for a very short time at CPO where concentrations were found to be similar to RGM levels. The role of particulate deposition in overall loading to Lake Ozette and Lake Dickey is largely unknown given the limited data available and current knowledge gaps concerning aerosol deposition in coastal locations. Additionally, coastal effects do not appear to be affecting tissue concentrations for Loomis Lake and Duck Lake included in the statewide lakes dataset. Mean mercury concentrations from 10 fish collected at Duck and Loomis were 247 and 311 respectively. Average fish length at Duck $(367 \mathrm{~mm})$ and Loomis $(354 \mathrm{~mm})$ were similar to Ozette $(342 \mathrm{~mm})$ and Dickey $(358 \mathrm{~mm})$. Both lakes are located along the Pacific Ocean south of Lake Ozette and Lake Dickey (Figure 2).

\subsection{Asian Mercury Sources}

Developing economies and increased energy needs have resulted in a transfer of dominant global emissions of atmospheric mercury from North America/Europe to Asia (Pacyna et al. 2006; Seigneur et al. 2001). Led by China, Asian sources emitted approximately 54\% of the global total in 2000 (Wu et al. 2006). Estimates for total Asian emissions including contributions from terrestrial surfaces range from 1260 $2270 \mathrm{Mg} / \mathrm{yr}$ (Jaffe et al. 2005; Pan et al. 2007; Strode et al. 2007). Increasing Asian mercury emissions have been of particular concern in the Western United States due to its position downwind from Asia (eg. Jaffe et al. 2005; Weiss-Penzias et al. 2003; Jaffe and Strode 2008). The unique far westerly location of Lake Ozette and Dickey places them as the closest lakes to Asia within the conterminous United States.

Asian air masses containing elevated levels of mercury have been documented at $\mathrm{CPO}$ and in central Oregon (Jaffe et al. 2005; Weiss-Penzias et al. 2006). The Asian air masses can reach the region in as little as 5 days and bear a similar signal to the global reservoir dominated by elemental mercury with a small percentage of RGM (Jaffe et al. 2005; Weiss-Penzias et al. 2003). Recent modeling studies examining the Asian contribution to deposition within the United States have found Asian deposition to be broadly dispersed due to elemental mercury being the dominate species. Location or orientation to Asia appears to be a less important factor controlling deposition than rates of in situ production of RGM from the Asian elemental mercury pool (Strode et al. 2007; Jaffe and Strode 2008). The near background concentrations recorded at the Ozette MDN station and CPO atmospheric monitoring indicate deposition to the area is not enhanced from direct transport of Asian mercury emissions.

\section{Summary and Conclusion}

The data presented in this paper document unprecedented concentrations of mercury in Washington State largemouth bass, which appears to be associated with logging in the catchment area of the lakes. Atmospheric concentrations and depositional data indicate the two lakes are relatively unaffected by local and regional point source polluters. In addition, there is no evidence that coastal processes are enhancing mercury fluxes to the lakes or their catchments. The high levels of contamination found in fish tissue at the lakes have occurred under atmospheric conditions near the global background. Sediment core data from both lakes indicates logging has greatly increased the net flux of mercury to the waterbodies. Clear-cut logging has been correlated with increased mercury and methylmerucry flux in other investigations. Specific factors influencing methylmercury production and biological uptake were beyond the scope of this study. Additional work is necessary to determine the relative contributions of catchment and in-lake processes to the elevated tissue levels.

\section{Acknowledgments}


The authors are grateful to the following individuals for their assistance in completing this study: Callie Meredith, Michael Friese, Dale Norton, Randy Coots, Art Johnson, Sara Sekerak, Valerie Partridge, and Dean Momohara with the Washington State Department of Ecology, Amy Lavoie with the U.S.

Environmental Protection Agency, and Oscar Pancorbo and Carol Batdorf at the Massachusetts Department of Environmental Protection. The use of brand names within the report are for informational purposes only and do not represent an endorsement of products by the Washington State Department of Ecology or U.S. Geological Survey. 


\section{References}

Appleby, P., Oldfield, F. (1978). The Calculation of Lead-210 Dates Assuming A Constant Rate of Supply of Unsupported ${ }^{210} \mathrm{~Pb}$ to the Sediment. Catena, Vol. 5, 1-8.

Appleby, P., Oldfield, F. (1984). Empirical Testing of ${ }^{210} \mathrm{~Pb}$-dating Models for Lake Sediments. In E. Haworth and G. Lund (Eds.), Lake Sediments and Environmental History (pp. 93-123). University of Minnesota Press.

Bloom, N., Prestbo, E., Tokos, J., Kuhn, E., von der Geest, E. (1995). Distribution of Mercury Species in the Pacific Northwest Atmosphere. Presented at the Mercury Deposition and Cycling Symposium, $210^{\text {th }}$ ACS Meeting, 1995.

Bortleson, G., Dion, N., McConnell, J., Nelson, L. (1976). Reconnaissance Data on Lakes in Washington: Clallam, Island, Jefferson, San Juan, Skagit, and Whatcom Counties. Water-Supply Bulletin 43, Vol. 1.

Cutshall, N.H., Larsen, I.L., Olsen, C.R. (1983). Direct analyses of ${ }^{210} \mathrm{~Pb}$ in sediment samples: self-absorption corrections. Nuclear Instruments and Methods 26, 309-312.

Engle, M., Tate, M., Krabbenhoft, D., Kolker, A., Olson, M., Edgerton, E., DeWild J., McPherson A. (2008). Characterization and Cycling of Atmospheric Mercury along the Central US Gulf Coast. Applied Geochemistry, doi:10.10lb/j.apgeochem.2007.12.12.024

Engstrom, D., Balogh, S., Swain, E. (2007). History of Mercury Inputs to Minnesota Lakes: Influences of Watershed Disturbance and Localized Atmospheric Deposition. Limnology and Oceanography, 52(6), 2467-2483.

Fischnaller, S., Anderson, P., Norton, D. (2003). Mercury in Edible Fish Tissue and Sediments from Selected Lakes and Rivers of Washington State. Washington State Department of Ecology, Environmental Assessment Program. Olympia, WA. Ecology Publication No. 03-03-026. http://www.ecy.wa.gov/biblio/0303026.html

Fitzgerald, W., Engstrom, D., Mason, R., Nater, E. (1998). The Case for Atmospheric Mercury Contamination in Remote Areas. Environmental Science and Technology, 32(1), 1-7.

Furl, C., Seiders, K., Alkire, D., and Deligeannis, C. (2007). Measuring Mercury Trends in Freshwater Fish in Washington State: 2005 Sampling Results. Washington State Department of Ecology, Environmental Assessment Program. Olympia, WA. Ecology Publication No. 07-03-007. http://www.ecy.wa.gov/biblio/0703007.html

Furl, C. (2007). Measuring Mercury Trends in Freshwater Fish in Washington State: 2006 Sampling Results. Washington State Department of Ecology, Environmental Assessment Program. Olympia, WA. Ecology Publication No. 07-03-043. http://www.ecy.wa.gov/biblio/0703043.html

Furl, C. (2007a). History of Mercury in Selected Washington Lakes Determined from Age-Dated Sediment Cores: 2006 Sampling Results. Washington State Department of Ecology, Olympia, WA. Publication No. 07-03-019. http://www.ecy.wa.gov/biblio/0703019.html

Furl, C., Meredith, C. (2008). Measuring Mercury Trends in Freshwater Fish in Washington State: 2007 Sampling Results. Washington State Department of Ecology, Environmental Assessment Program. Olympia, WA. Publication No. 08-03-027 http://www.ecy.wa.gov/biblio/0803027.html

Furl, C. (2008). History of Mercury in Selected Washington Lakes Determined from Age-Dated Sediment Cores: 2007 Sampling Results. Washington State Department of Ecology, Olympia, WA. Publication No. 08-03-012. http://www.ecy.wa.gov/biblio/0803012.html

Garcia, E., Carignan, R. (1999). Impact of Wildfire and Clear-cutting in the Boreal Forest on Methyl Mercury in Zooplankton. Canadian Journal of Fisheries and Aquatic Sciences, 56, 339-345.

Garcia, E., Carignan, R. (2000). Mercury Concentrations in Northern Pike (Esox lucius) from Boreal Lakes with Logged, Burned, or Undisturbed Catchments. Canadian Journal of Fisheries and Aquatic Sciences, 57 (Suppl. 2), 129-135.

Grieb, T.M., Driscoll, C.T., Gloss, S.P., Schofield, C. L., Bowie, G.L., Porcella, D.B. (1990). Factors Affecting Mercury Accumulation in Fish in the Upper Michigan Peninsula. Environmental Toxicology and Chemistry, Vol. 9, 919-930.

Grigal, D. (2002). Inputs and Outputs of Mercury from Terrestrial Watersheds: A Review. Environmental Reviews, 10, 1-39.

Haggerty, M.J., Ritchie, A.C., Shellberg, J.G., Crewson, M.J., Jalonen, J. (2007). Lake Ozette Sockeye Limiting Factors Analysis: Draft 8_1. Prepared for the Makah Indian Tribe and NOAA Fisheries in Cooperation with the Lake Ozette Sockeye Steering Committee, Port Angeles, WA. Accessed 25 July 2008. http://noplegroup.org/NOPLE/pages/watersheds/OzetteLakeWatershedPage.htm 
Hanten, R.P., Neuman, R.M., Ward, S.M., Carley, R.J., Perkings, C.R., Pirrie, R. (1998). Relationships between Concentrations of Mercury in Largemouth Bass and Physical and Chemical Characteristics of Connecticut Lakes. Transactions of the American Fisheries Society, Vol. 127, 807-818.

Hedgecock, I., Pirrone, N. (2001). Mercury and Photochemistry in the Marine Boundary Layer - Modeling Studies Suggest the in situ Production of Reactive Gas Phase Mercury. Atmospheric Environment, 35, 3055-3062.

Herrera Environmental Consultants. (2006). Reconnaissance study of geomorphic conditions: Lake Ozette watershed. Unpublished report prepared for Olympic National Park, 154 pp. plus appendices, Port Angeles, WA.

Hrabik, T.R., Watras C.J. (2002). Recent Declines in Mercury Concentration in a Freshwater Fishery: Isolating the Effects of DeAcidification and Decreased Atmospheric Mercury Deposition in Little Rock Lake. The Science of the Total Environment, Vol. 297, 229-237.

Jaffe, D., Prestbo, E., Swartzendruber, P., Weiss-Penzias, P., Kato, S., Takami, A., Hatakeyama, S., Kajii, Y. (2005). Export of Atmospheric Mercury from Asia. Atmospheric Environment, 39, 3029-3038.

Jaffe, D. and Strode, S. (2008). Sources, Fate and Transport of Atmospheric Mercury from Asia. Environmental Chemistry, 5, 121126.

Landers, D.H., Simonich, S.L., Jaffe, D.A., Geiser, L.H., Campbell, D.H., Schwindt, A.R., Schreck, C.B., Kent, M.L., Hafner, W.D., Taylor, H.E., Hageman, K.J., Usenko, S., Ackerman, L.K., Schrlau, J.E., Rose, N.L., Blett, T.F., Erway, M.M. (2008). The Fate, Transport, and Ecological Impacts of Airborne Contaminants in Western National Parks (USA). EPA/600/R07/138. U.S. Environmental Protection Agency, Office of Research and Development, NHEERL, Western Ecology Division, Corvallis, Oregon.

Laurier, F., Mason, R. (2007). Mercury Concentration and Speciation in the Coastal and Open Ocean Boundary Layer. Journal of Geophysical Research, doi:10.1029/2006JD007320.

Lindberg, S., Brooks, S., Lin, C., Scott, K., Landis, M., Stevens, R., Goodsite, M., Richter, A. (2002). Dynamic Oxidation of Gaseous Mercury in the Arctic Troposphere at Polar Sunrise. Environmental Science and Technology, 36, 3000-3009.

Malcolm, E., Keeler, G. (2003). The Effects of the Coastal Environment on the Atmospheric Mercury Cycle. Journal of Geophysical Research, doi: 10.1029/2002JD003084.

Mercury Deposition Network. (2008). Monitoring Mercury Deposition A Key Tool to Understanding the Link between Emissions and Effects. NADP Program Office, Illinois State Water Survey, 2204 Griffith Dr., Champaign, IL 61820. http://nadp.sws.uiuc.edu/lib/brochures/mdn.pdf Accessed 22 October 2008.

Pacyna, E. G., Pacyna, J. M., Steenhuisen, F., Wilson, S. (2006). Global anthropogenic mercury emission inventory for 2000. Atmospheric Environment, doi:10.1016/J.ATMOSENV.2006.03.041

Pan, L., Chai, T., Carmichael, G. R., Tang, Y., Streets, D., Woo, J. H., Friedli, H. R., Radke, L. F. (2007) Top-down estimate of mercury emissions in China using four-dimensional variational data assimilation. Atmospheric Environment, doi:10.1016/J.ATMOSENV.2006.11.048

Porvari, P., Verta, M., Munthe, J., Haapanen, M. (2003). Forestry Practices Increase Mercury and Methyl Mercury Output from Boreal Forest Catchments. Environmental Science and Technology, 37, 2389-2393.

Ritchie, A. (2009). A late quaternary sediment source and deposition history of Lake Ozette, Olympic National Park, Washington. Report to the National Park Service. Department of Earth and Space Sciences, University of Washington.

Seigneur, C., Karamchandani, P., Lohman, K., Vijayaraghavan, K., Shia, R. (2001). Multiscale Modeling of the Atmospheric Fate and Transport of Mercury. Journal of Geophysical Research, 106 (D21), 27,795-27,809.

Schroeder, W., Munthe, J. (1998). Atmospheric Mercury - An Overview. Atmospheric Environment, 32(5), 809-822.

Strode, S.A., Jaegle, L., Jaffe, D., Swartzendruber, P., Selin, N., Holmes, C., Yantosca, R. (2007). Trans-Pacific Transport of Mercury. Journal of Geophysical Research, 113 (D15305), doi:10.1029/2007JD009428.

Temme, C., Einax, J., Ebinghaus, R., Schroeder, W. (2003). Measurements of Atmospheric Mercury Species at a Coastal Site in the Antartic and over the South Atlantic Ocean during Polar Sunrise. Environmental Science and Technology, 37, 22-31.

USGS. (2007), U.S. Geological Survey Mineral Resources On-line Spatial Data. http://tin.er.usgs.gov/. Accessed 10 December 2008.

Weiss-Penzias, P., Jaffe, D., Mcclintick A., Prestbo, E., Landis, M. (2003). Gaseous Elemental Mercury in the Marine Boundary Layer: Evidence for Rapid Removal in Anthropogenic Pollution. Environmental Science and Technology, 37, 3755-3763.

Weiss-Penzias, P., Jaffe, D. A., Swartzendruber, P., Dennison, J. B., Chand, D., Hafner W., Prestbo, E. (2006). Observations of Asian air pollution in the free troposphere at Mt. Bachelor Observatory in the spring of 2004. Journal of Geophysical Research, 110 D10304, doi:10.1029/2005JD006522. 
Wu, Y., Wang, S., Streets, D. G., Hao, J., Chan, M., Jiang, J. (2006). Trends in anthropogenic mercury emissions in China from 1995 to 2003. Environmental Science and Technology, doi:10.1021/ES060406X. 


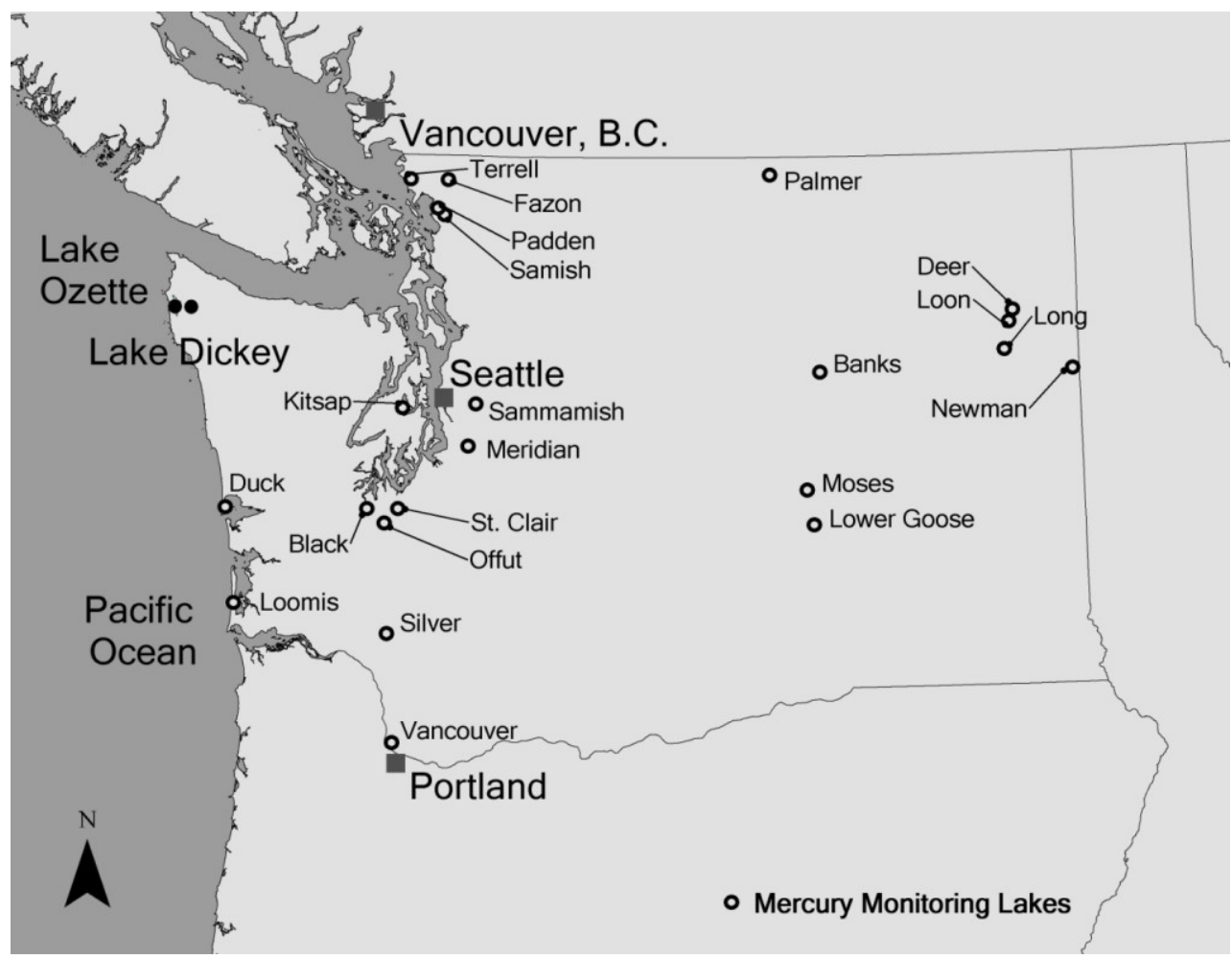

Fig. 1 Study lakes locations along with major population centers in Oregon, Washington, and British Columbia 


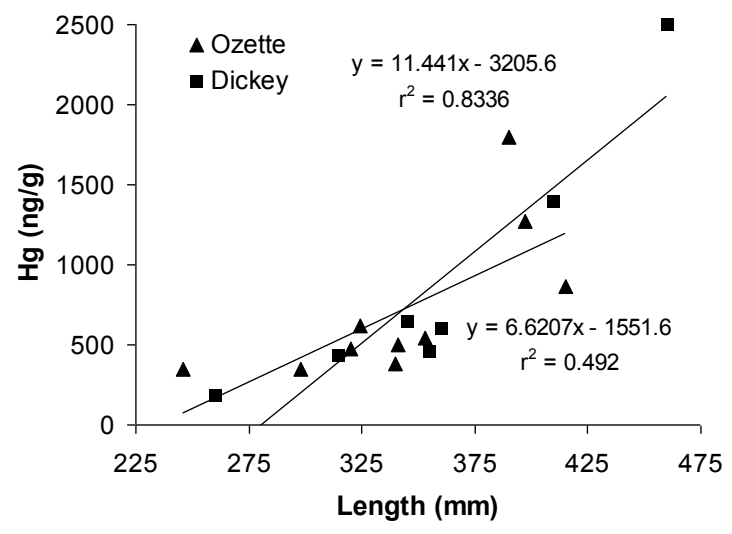

Fig. 2 Fish Tissue Concentrations versus Length for Lake Ozette and Dickey 


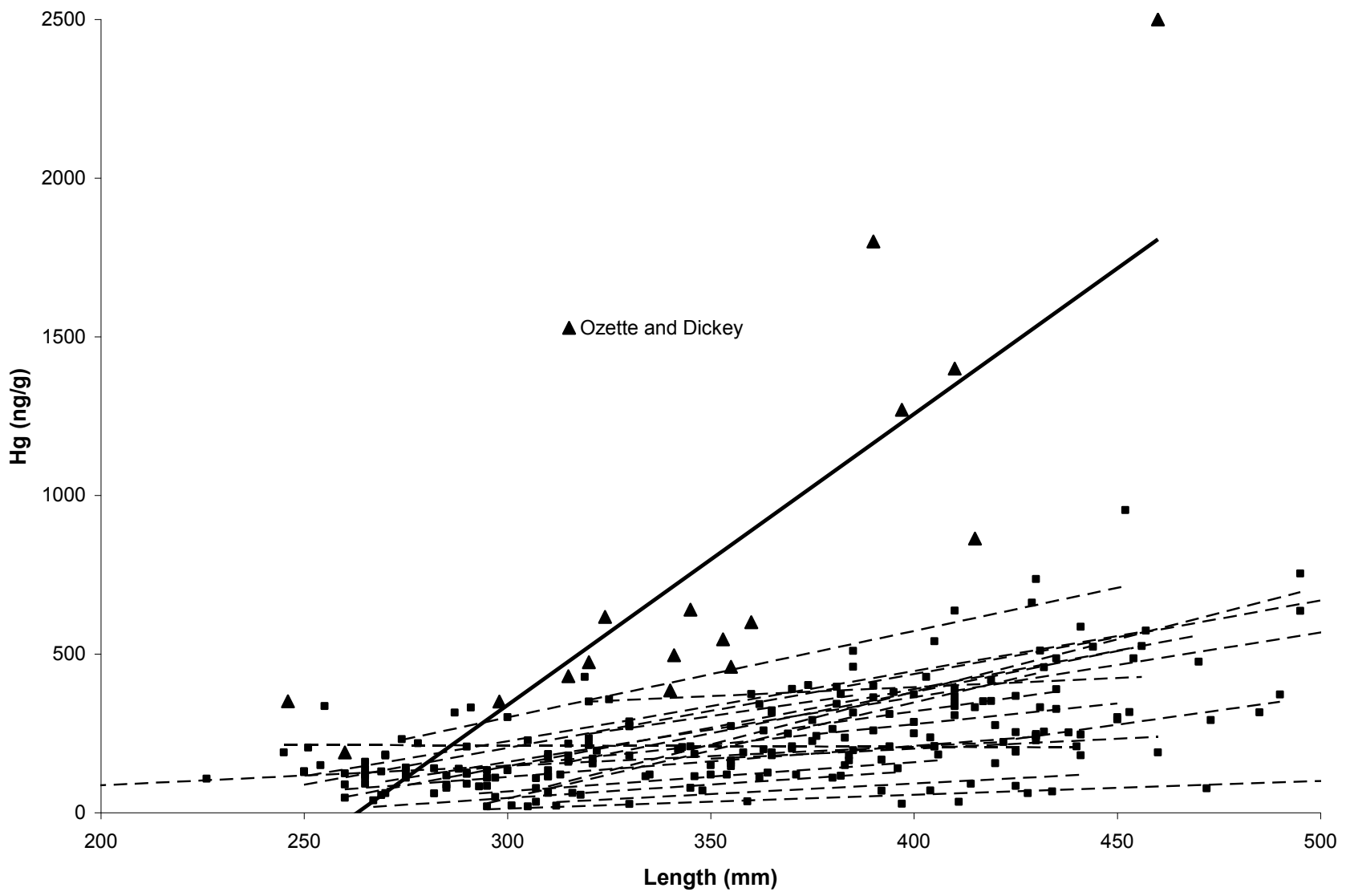

Figure 3. Mercury Regressions against Fish Length for Combined Lake Ozette and Lake Dickey data and all Statewide Lakes 

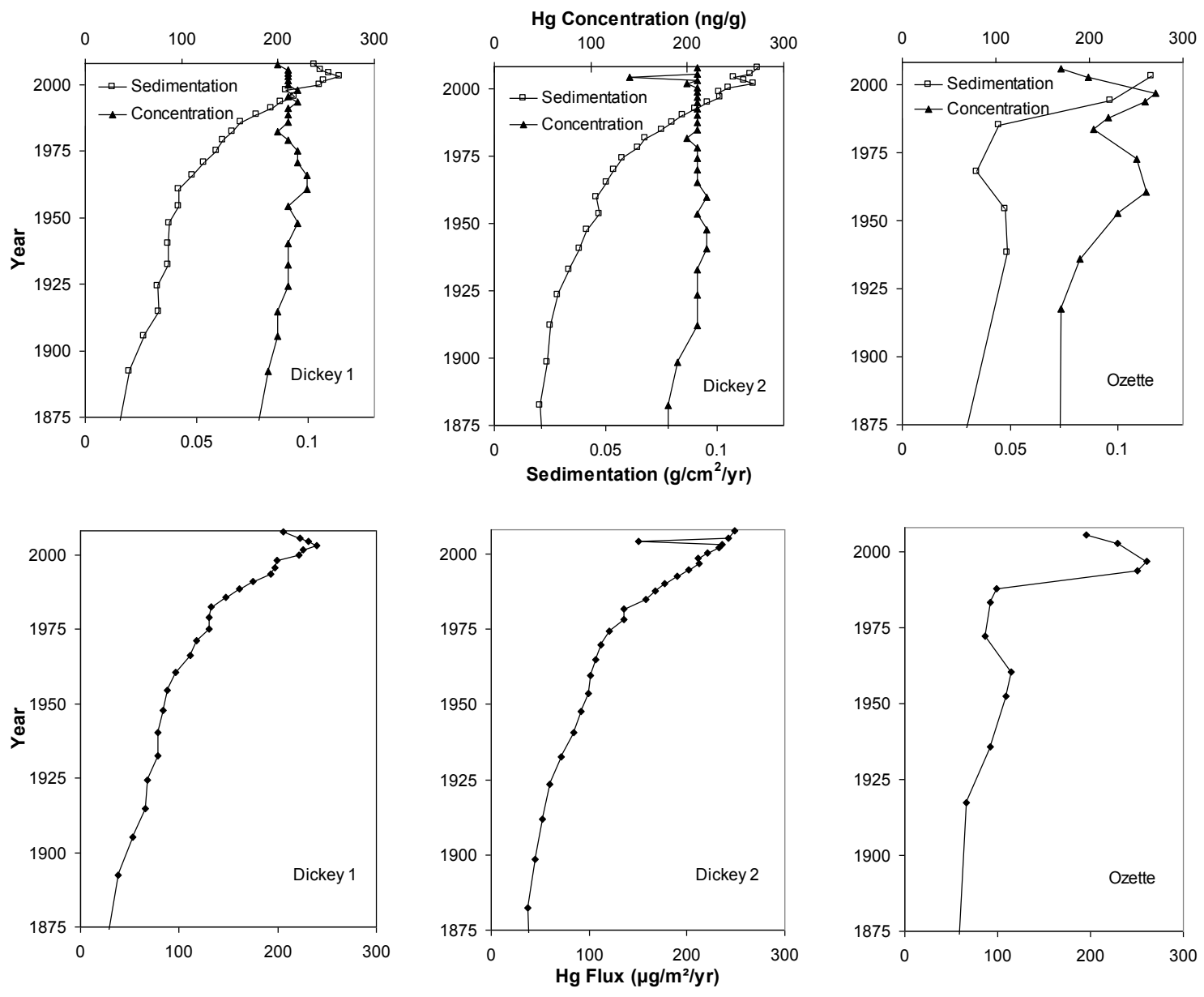

Fig. 4 Sediment Core Concentrations, Sedimentation Rates, and Flux Profiles 

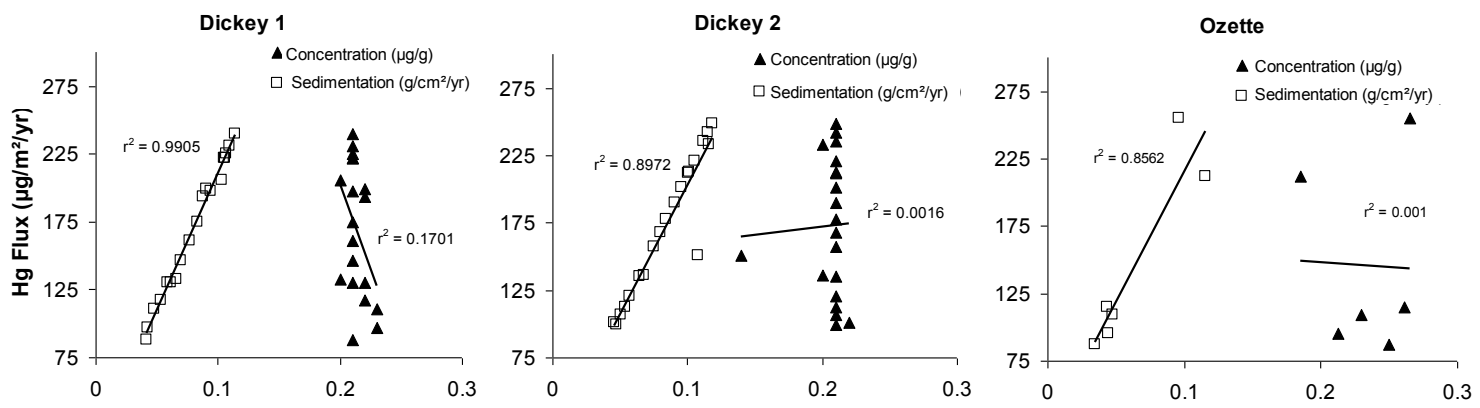

Fig. 5 Post - 1950 mercury flux rates plotted with sedimentation rates and mercury concentrations 

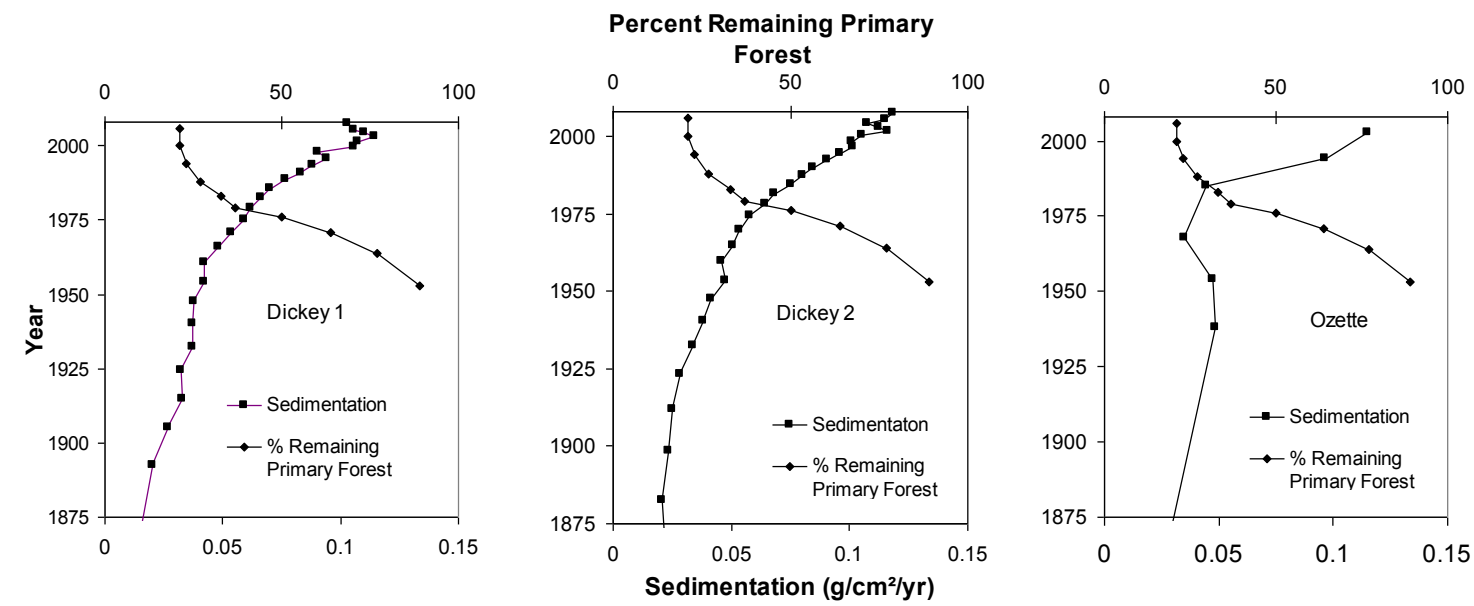

Fig. 6 Estimated Sedimentation Rates plotted with Percent Remaining Primary Forest (Ritchie 2009) in the Ozette Drainage Basin 